\title{
ロール絞り作用に影響在およ㴽す要因*
}

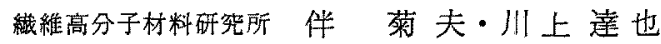

\section{ON THE FACTORS GOVERNING THE EFFICIENCY OF MANGLING}

\author{
By Kikuo Ban and Tatsuya Kawakami
}

(Research Institute for Polymers and Textiles, 4, Sawatari,

Kanagawa-ku, Yokohama, Japan)

The effcts of total load, hardness of roller cover and speed of cloth on the water retained in fabric after mangling ware investigated. At first, a three-factor factorial experiment in a parametric model was used. In this experiment factor A (total load) has 8 levels, factor B (cloth speed) 5 levels and factor $C$ (cover hardness) 4 levels, and entire experiment is replicated seven times. The results of analysis of variance show that factor $A$ and $C$ are highly significant but $B$ is less when using a $1 \%$ level of significance. Next, the principal factor analysis is used to determine the minimum number of dimensions needed to account for the variance in the original set of variables. In this analysis the numbers of dimension of variable spaces are 96 (total load 8 , speed 3 , hardness 4 ) and 36 (total load 3 , speed 3 , hardness 4 ), respectively.

It is confirmed that $75 \%$ of total variance is explained sufficiciently with three eigenvalues in the order of reducing magnitude.

(Received May 21, 1969)

\section{1. 緒言}

パディングならびルマングリングに使用されているロ ール工程の動特性を明らかにするたるに本奏験を計画し た。本報告汇関係する従来の研究としては H. Rath, E. Selter らの報告が見られる゙。 Rath らは死力と平衡水 分量の測定方ら始めて, 校りロ一ルの平均圧力, 温度, 速度, 陚料などの变化に対する付着量の変化を測定して いるが、それらの要因の組合せによる絞り工程動特性の 数学モデルに関する実験は行なわれていない。

本実験ではロール硬度，表面速度ならびに荷重を変化 させた時の放り付着量の变化を多変量解析の手法を利用 して明らかにし，動的絞り作用の数学モデルを作成する ための資料を得ようとするすのである。そこでまず棱り 付着量に影響を及ぼす因子を分散分析により明確にし， ついで主园子分析によって全分散の 70 80\%を説明す ることのできる共通因子を見出し，さらに因子負荷行列 を求めてその構造模形と比較检討寸る。

\section{2. 実 験 装 置}

幅 $300 \mathrm{~mm}$ 外径 $160 \mathrm{~mm}$ のステンレスロールと同幅

*この報文を「ロール絞り作用の動特性に関方石研究 (第1 報) Dynamical characteristics of mangling action (Part 1)」とする。

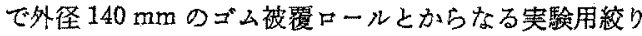
装筧を使い，科量法により筡り上り重量を測定した。ゴ

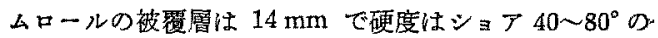
ものをそれそれ取りかえて使用した。試料は40 番ブロ 一ト $(240 \mathrm{~mm} \times 260 \mathrm{~mm})$ を糊抜きしたものをくり方 して使った。付着量は摽準状態でほぼ平悳に達した時の 試料乾燥重量 $x_{0}$ を測定しておき，絞り上り重量測定值

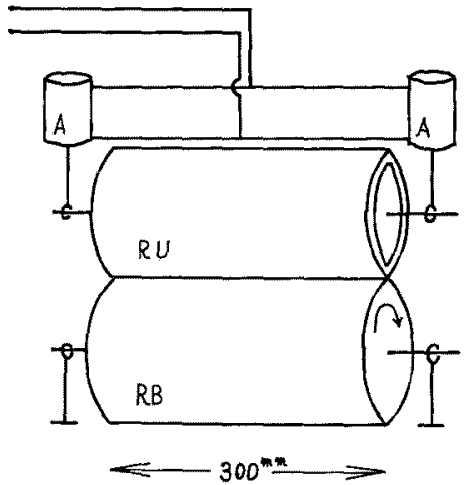

Fig. 1 Schematic diagram of experimental appratus. Rubber-covered roller $R U$ is loaded with two air cylinders $A$, and metal roller $R B$ is connected to an electric motor through a variablespeed transmission. 
Table 1.1 Air pressure and load per linear $\mathrm{cm}$ of the experimental apparatus.

\begin{tabular}{l|llllllll}
\hline air pressure $\left(\mathrm{kg} / \mathrm{cm}^{2}\right)$ & 0.6 & 1.0 & 1.4 & 1.8 & 2.2 & 2.6 & 3.0 & 3.4 \\
\hline load $(\mathrm{kg} / \mathrm{cm})$ & 2.09 & 2.61 & 3.14 & 3.66 & 4.18 & 4.71 & 5.23 & 5.75
\end{tabular}

$+\mathrm{ACR}+\mathrm{BCR}+\mathrm{ABCR}$ とし部算し だ。 Table 2 からAならびにC因 子は問題なく付着量変化に大きな影 響を及隹していることがわかる。す なわり供給空気圧を变えてすロール
Table 1.2 Graduation of variable-speed transmission and cloth speed.

\begin{tabular}{l|ccccc}
\hline graduation & 0.0 & 2.5 & 5.0 & 7.5 & 10.0 \\
\hline speed $(\mathrm{m} / \mathrm{min})$ & 4.38 & 8.19 & 12.99 & 18.38 & 24.31 \\
\hline
\end{tabular}

$x$ から $\left(x-x_{0}\right) / x_{0}$ として求めた。ロール采は Fig.1 に 示すように2本のエアシリンダで荷重するよらになって

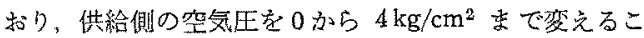
とによって荷重を变化させることができるようになって いる。ロール表面速度は無段変速器によって变えること ができ，その変化範圈は Table 1.1，Table 1.2 K示方 と和りである。

\section{3. 分散分析実験計画}

ロール加压用の供給空気压と变速器の目盛とロール硬 度とをそれぞれA，B，C制御因子として繰返しのある 母数型分散分析を計画した。ロール加圧用の供給空気王 因子(A因子) 0.6 から $3.4 \mathrm{~kg} / \mathrm{cm}^{2}$ までを $0.4 \mathrm{~kg} / \mathrm{cm}^{2}$ おきに 8 本準とり，表面速度因子（B因子）は変速器の 全目盛を 4 等分して 5 氷集とし， F一兀硬度因子（C因 子) $40^{\circ}, 60^{\circ}, 75^{\circ}, 88^{\circ} の 4$ 水準とした。すなから荷 重としては算位長さ当り 2.09 から $5.75 \mathrm{~kg} / \mathrm{cm}$ ，表面 速度としては 4.38 から $24.31 \mathrm{~m} / \mathrm{min}$ をガーしてい る。繰返しの回数については第 2 種の過誤 $\beta$ に焦点を置 いて理論的に求める方法があるが，本質的に $\beta$ をいくら にしたらよいのかという点を決定しかねたので本実騃で は田口の推奖する Baye's Wald の解に叔ける

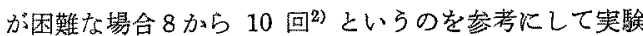
の都合により7回と決めだ。卖駼順序はランダムな 4 水 準の硬度因子に対して，供給空気生因子8水準と表面速 度因子 5 水準の組み合せとして，それぞれ 40 回の無作 為配置を作りこれを繰返し1回（R因子とする）とし， 毎回無作為配管表を作りなおして 7 回の繰返し実験を行 なった。次に各硬度に括子る速度因子の有意性を見るた めに A，B，R因子はそのますでC因子をばらばらにして 4 回の繰返しのまる2 元配置とてて計算した。

\section{4. 莶 験 結 果}

ます最初以繰返しの放る3元配置の分散分析結果を Table 2 K示す。愦差項は $\mathrm{R}+\mathrm{AR}+\mathrm{BR}+\mathrm{ABR}+\mathrm{CR}$
Table 2. Three-factor analysis of variance with replication.

\begin{tabular}{l|r|r|r|r}
\hline $\begin{array}{l}\text { source of } \\
\text { variation }\end{array}$ & $\begin{array}{c}\text { sums of } \\
\text { squares }\end{array}$ & $\begin{array}{c}\text { degrees of } \\
\text { freedom }\end{array}$ & $\begin{array}{c}\text { mean } \\
\text { squares }\end{array}$ & F value \\
\hline $\mathrm{A}$ & 24485.9 & 7 & 3497.9 & $1723.6^{* *}$ \\
$\mathrm{~B}$ & 19.5 & 4 & 4.8 & 2.36 \\
$\mathrm{AB}$ & 189.7 & 28 & 6.7 & $3.30^{* *}$ \\
$\mathrm{C}$ & 19662.3 & 3 & 6554.1 & $3229.5^{* *}$ \\
$\mathrm{AC}$ & 460.0 & 21 & 21.9 & $10.7^{* *}$ \\
$\mathrm{BC}$ & 398.9 & 12 & 33.2 & $16.3^{* *}$ \\
$\mathrm{ABC}$ & 208.6 & 84 & 2.4 & 1.18 \\
$\mathrm{R}$ & 98.0 & 6 & 16.3 & \\
$\mathrm{AR}$ & 49.4 & 42 & 1.1 & \\
$\mathrm{BR}$ & 37.6 & 24 & 1.5 & \\
$\mathrm{ABR}$ & 179.1 & 168 & 1.0 & \\
$\mathrm{CR}$ & 676.0 & 18 & 35.7 & \\
$\mathrm{ACR}$ & 197.6 & 126 & 1.5 & \\
$\mathrm{BCR}$ & 141.7 & 72 & 1.9 & \\
$\mathrm{ABCR}$ & 568.9 & 504 & 1.1 & \\
\hline Total & 47373.9 & 1119 & & \\
Error & 1948.3 & 960 & 2.02 & \\
\hline
\end{tabular}

硬度を変えても，その結果として絞り付着呰には有意な 変化が見られる。交互作用 $\mathrm{AC}, \mathrm{BC}$ が有意となってい るのは A，C ならびに B，C がそれぞれ直交していな いといらことで希。速度因子Bについては $1 \%$ 有意に わずかにみたないがここの程度の速度変化では付着量に 有意な差として影響するだけの要因とはなり得ない。次 に各便度別に繰返しの方 2 元配置として計算した結果 を Table 3.1 から Table 3.4 K示与。速鹿图于につい ては硬度が大きくなると，市なから $75^{\circ}$ と $88^{\circ}$ との場合 には速度に上る付着量の变化が明確に出てくる。そこで 各硬度に和ける付着䁷の变化を速度に対して図示吉ると Fig. 2(a) から Fig.2(d) までのようになる。Fig.2(a)， （b）加ら硬度 $40^{\circ} 60^{\circ}$ に扣いては，単位長さ当りの荷重 が $2.09 \mathrm{~kg} / \mathrm{cm}$ の荡合にわずか心速度の影響が見られる が，艺れ以外㯈度よる变化性諗められない。硬度 $75^{\circ}$ の場合には Fig. 2(c) に示导よ5に単位長さ当りの 荷重が $3.14 \mathrm{~kg} / \mathrm{cm}$ 以上になると，速度が增加场るにつ れて絞り效果が悪くなって行くのが見られる。Fig.2(d) に示すように硬度 $88^{\circ}$ の昜合には全体的に速度の効果が 見られるが，特に影響が大きいのは $75^{\circ}$ の場台とは逆に 

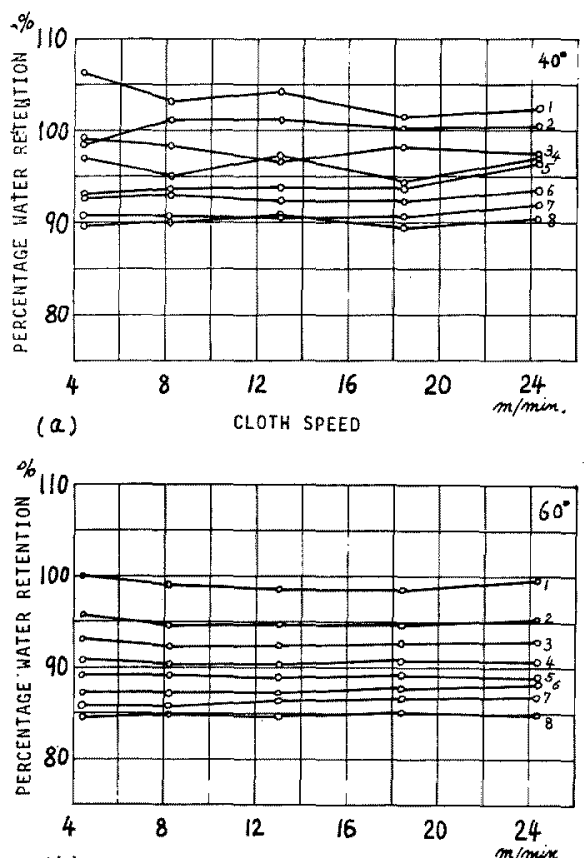

(b)

CLOTH SPEED

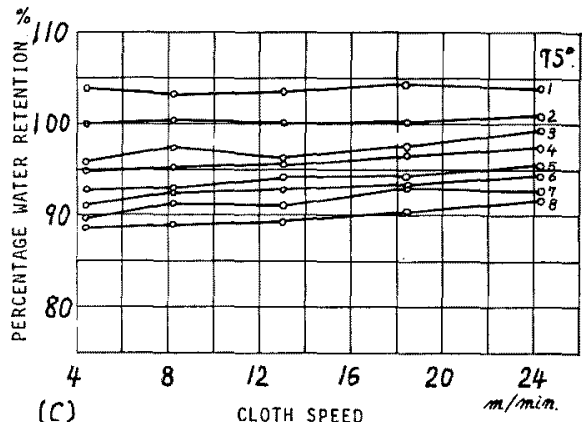

(C)

CLOTH SPEED

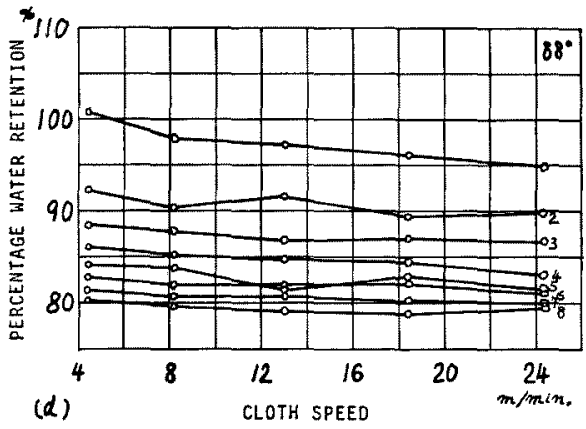

Fig. 2. Effects of cloth speed on water take-up when the hardness of cover is equal to $40^{\circ}$. The figures alongside the data indicate the level of total load.
Table 3.1 Two-factor analysis of variance when hardness is equal to $40^{\circ}$

\begin{tabular}{l|r|r|r|r}
\hline $\begin{array}{l}\text { source of } \\
\text { variation }\end{array}$ & $\begin{array}{r}\text { sums of } \\
\text { squares }\end{array}$ & $\begin{array}{c}\text { degrees of } \\
\text { freedom }\end{array}$ & $\begin{array}{c}\text { mean } \\
\text { squares }\end{array}$ & F value \\
\hline A & 5434.6 & 7 & 776.3 & $685.1^{* *}$ \\
B & 30.4 & 4 & 7.6 & $6.72^{* *}$ \\
AB & 207.4 & 28 & 7.4 & $6.53^{* *}$ \\
R & 3.2 & 9 & 0.5 & \\
AR & 55.6 & 42 & 1.3 & \\
BR & 27.9 & 24 & 1.1 & \\
ABR & 185.0 & 168 & 1.1 & \\
\hline Total & 5944.5 & 279 & & \\
Error & 271.9 & 240 & 1.13 & \\
\hline
\end{tabular}

Table 3.2 Two-factor analysis of variance when hardness is equal to $60^{\circ}$

\begin{tabular}{l|r|r|r|c}
\hline $\begin{array}{l}\text { source of } \\
\text { variation }\end{array}$ & $\begin{array}{c}\text { sums of } \\
\text { squares }\end{array}$ & $\begin{array}{c}\text { degrees of } \\
\text { freedom }\end{array}$ & $\begin{array}{c}\text { mean } \\
\text { squares }\end{array}$ & F value \\
\hline $\mathrm{A}$ & 5424.8 & 7 & 774.9 & $381.3^{* * *}$ \\
$\mathrm{~B}$ & 11.1 & 4 & 2.7 & 1.37 \\
$\mathrm{AB}$ & 29.8 & 28 & 1.0 & 0.52 \\
$\mathrm{R}$ & 213.4 & 6 & 35.5 & \\
$\mathrm{AR}$ & 73.9 & 42 & 1.7 & \\
$\mathrm{BR}$ & 60.2 & 24 & 2.5 & \\
$\mathrm{ABR}$ & 140.0 & 168 & 0.8 & \\
\hline Total & 5953.5 & 279 & & \\
Error & 487.6 & 240 & 2.03 & \\
\hline
\end{tabular}

Table 3.3 Two-factor analysis of variance when hardness is equal to $75^{\circ}$

\begin{tabular}{l|r|r|r|r}
\hline $\begin{array}{l}\text { source of } \\
\text { variation }\end{array}$ & $\begin{array}{c}\text { sums of } \\
\text { squares }\end{array}$ & $\begin{array}{c}\text { degrees of } \\
\text { freedom }\end{array}$ & $\begin{array}{c}\text { mean } \\
\text { squares }\end{array}$ & F value \\
\hline $\mathrm{A}$ & 5345.7 & 7 & 763.6 & $222.4^{* *}$ \\
$\mathrm{~B}$ & 176.6 & 4 & 44.1 & $12.8^{* *}$ \\
$\mathrm{AB}$ & 58.6 & 28 & 2.0 & 0.6 \\
$\mathrm{R}$ & 503.1 & 6 & 83.8 & \\
$\mathrm{AR}$ & 53.8 & 42 & 1.2 & \\
$\mathrm{BR}$ & 65.9 & 24 & 1.1 & \\
$\mathrm{ABR}$ & 200.9 & 168 & & \\
\hline Total & 6404.8 & 279 & & \\
Error & 823.8 & 240 & 3.43 & \\
\hline
\end{tabular}

(a) : a $95 \%$ confidence interval for mern is $\nearrow$

(b):

$\pm 2.3 \%$

(c):

$\pm 2.6 \%$

$\pm 3.4 \%$

(d):

$\pm 3.1 \%$ 
Table 3.4 Two-factor analysis of variance when hardness is equal to $88^{\circ}$

\begin{tabular}{l|r|r|r|r}
\hline $\begin{array}{l}\text { source of } \\
\text { variation }\end{array}$ & $\begin{array}{c}\text { sums of } \\
\text { squares }\end{array}$ & $\begin{array}{c}\text { degrees of } \\
\text { freedom }\end{array}$ & $\begin{array}{c}\text { mean } \\
\text { squares }\end{array}$ & F valus \\
\hline $\mathrm{A}$ & 8740.8 & 7 & 1248.6 & $820.2^{* * *}$ \\
$\mathrm{~B}$ & 200.2 & 4 & 50.0 & $32.8^{* *}$ \\
$\mathrm{AB}$ & 102.4 & 28 & 3.6 & $2.4^{* *}$ \\
$\mathrm{R}$ & 54.2 & 6 & 9.0 & \\
$\mathrm{AR}$ & 63.7 & 42 & 1.5 & \\
$\mathrm{BR}$ & 25.2 & 24 & 1.0 & \\
ABR & 222.1 & 168 & 1.3 & \\
\hline Total & 9408.8 & 279 & & \\
Frror & 365.3 & 240 & 1.52 & \\
\hline
\end{tabular}

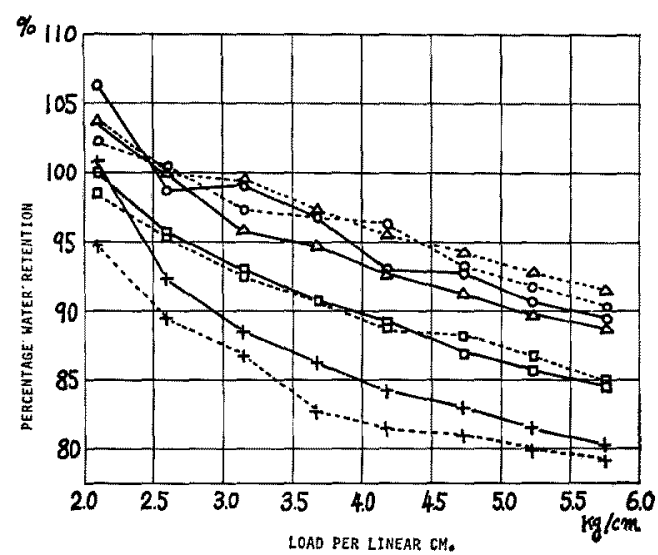

Fig. 3. Effects of cloth speed and cover hardness on water take-up.

Cloth speed : straight line $; 4.38 \mathrm{~m} / \mathrm{min}$. dotted line $; 24.31 \mathrm{~m} / \mathrm{min}$.

Shore hardness : $O: 40^{\circ}, \square: 60^{\circ}, \triangle: 75^{\circ}$ $+: 88^{\circ}$

単位長さ当りの荷重が最小の場合であり，しがも速度が 增加するにつれて舷り効果がよくなって行く傾向が見ら れる。各硬度間の差を冒るために付着量の変化を単位長

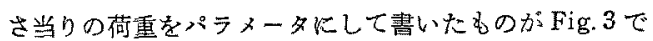
める、この图から判定すると最も皎り效率のよいのは $88^{\circ}$ の場合であり，次いで $60^{\circ}, 75^{\circ}, 40^{\circ}$ とい5順に熹 くなっていくことがおかる。

\section{5. 多変量解析のための考察}

全体として速度効果恼㐫り見られないが研度の高い 場合に若干その影響が認められるので，速度因子を1水 準おきに取って 3 算数とし供給側の空気压因子は単位長 さ当りの荷重に換算して8変数上し硬度す乞のま 4 亲
数として全部で 96 次元の変数空間 (ニークリッドペク トル架開）を考えると，分散にはノルムの2 乘を共分散 (または相関保数)にはペクトルの内積をあてはめるこ そができる。そこで絞り作用の数学モデルとして次のよ らな因子分析モデルを考文る。

$$
x_{i}=\mu_{i}+\sum_{j=1}^{m} l_{i j} f_{j}+s_{i} \quad(i=1,2, \cdots, 96)
$$

$x_{i} ， \mu_{i}$ はテスト変数としての付着量と只の平均， $f_{\jmath}$ は

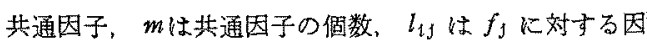
子負荷㽬であり $s_{i}$ は䛊差因子である。共通因子数 $m$ に ついは本夷験の諹合荷重，ロール王力分布，速度，布 地の王縮特性などをるげるこどできるが，少なくとる 96 よりは小さいと考皇てもさしつがない。 $f_{j}, s_{i}$ 忙 確率変数で互いに独立であると仮定しそれぞれの平均， 分散、共分散について次のような仮定を圜く。

$$
\begin{array}{ll}
E\left(f_{j}\right)=0, & E\left(s_{i}\right)=0 \\
V\left(f_{j}\right)=1, & V\left(s_{i}\right)=v_{1} \\
C_{0 V}\left(f_{j}, f_{k}\right)=0, & C_{0 V}\left(s_{i}, s_{k}\right)=0
\end{array}
$$

$j \neq k, i \neq k, f_{j}, f_{k}$ については $j, k=1,2, \cdots, m, s_{i}, s_{k}$ に ついては $i, k=1,2, \cdots, 96$ すると次の関係が得られる。

$$
\Sigma=B B^{\prime}+V
$$

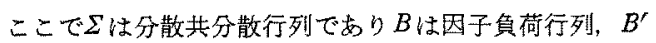
は車固行列，Vは対角な愦因子行列である。これを 相関掭数行列 $R$ を使って畫くと

$$
R=L L^{\prime}+S
$$

相関行列 $R$ かららL $L$ を推定するにはをントセイド法、 主因子分析，最尤法，Jöreskog の方法などがあるが， 本実験では主因子分析法により $L, S$ 党推定する，すな わらRの代りにその推定值 $A$ を用いて $A-S$ の固有值を 求め全体の分散の 70 から $80 \%$ を説明できる因子の㑑 数的を見つ计出しそれを共通因子数とする。誤差分散 $s_{\text {け }}$ の上限は变数 $x_{t}$ の他の 95 個の变数に対する重相関俰

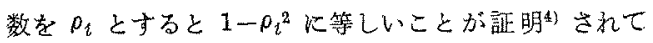

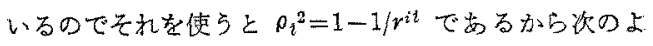
らに書くことができる。

$$
0 \leq s_{i} \leq 1 / r^{2 t}
$$

ここで $r^{\imath}$ はRの逆行列の対角成分である。

\section{6. 計算結果とその考察}

まず変数を96とした時の $A$-Sの固有值と乞の累㺓 值之老 Table 4.1 k示す，次以分析結果の安定性すな わちデータの增隇によって結果が大きく变和るかとらか

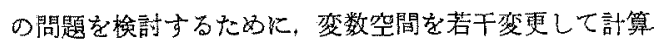
してみた結果を Table 4.2 加ら Table 4.4 亿示す。 Table 4.2 は王力 3 変数, 速度 3 変数, 硬度 4 变数, Table 4.3 法王力 1 変数, 速度 3 変数, 硬度 4 変数, 
Table 4.1. Eigenvalues and those cumulative percentage of 96 valiable space. (load 8, speed 3 , hardness 4)

\begin{tabular}{l|cccccc}
\hline eigenvalue & 34.8 & 18.7 & 13.8 & 10.8 & 9.4 & 8.2 \\
\hline percentage & 36 & 55 & 70 & 81 & 91 & 99 \\
\hline
\end{tabular}

Table 4.2. Eigenvalues and those cumulative percentage of 36 valiable space. (load 3 , speed 3 , hardness 4)

\begin{tabular}{l|ccccccc}
\hline eigenvalue & 14.7 & 7.1 & 4.7 & 3.8 & 2.9 & 2.5 \\
\hline percentage & 41 & 60 & 74 & 84 & 92 & 99 \\
\hline
\end{tabular}

Table 4.3. Eigenvalues and those cumulative percentage of 12 valiable space. (load 1, speed 3 , hardness 4)

\begin{tabular}{l|cccccc}
\hline eigenvalus & 5.3 & 3.4 & 1.5 & 0.95 & 0.42 & 0.22 \\
\hline percentage & 44 & 73 & 86 & 94 & 98 & 99 \\
\hline
\end{tabular}

Table 4.4. Eigenvalues and those cumulative percentage of 8 valiable space. (load 1 , speed 2, hardness 4)

\begin{tabular}{l|cccccc}
\hline eigenvalue & 4.2 & 1.8 & 1.0 & 0.69 & 0.11 & 0.04 \\
\hline percentage & 52 & 75 & 89 & 98 & 99 & 99 \\
\hline
\end{tabular}

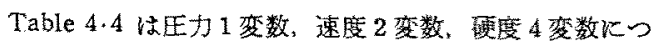

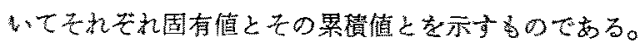

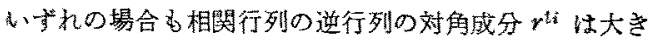
な供になり，考の连数は $10^{-5}$ 程度になるので主成分分

Table 5. Three-factor experimental arrangements. The figures $1 \sim 96$ correspond to the rotated factor loadings of fig. 4 .

\begin{tabular}{|c|c|c|c|c|c|c|c|c|c|}
\hline \multirow[b]{2}{*}{ hardness } & \multirow{2}{*}{$\begin{array}{c}\text { speed } \\
(\mathrm{m} / \mathrm{m} \mathrm{n})\end{array}$} & \multicolumn{8}{|c|}{ load per linear $\mathrm{cm}$} \\
\hline & & 2.09 & 2.61 & 3,14 & $\begin{array}{l}3.66 \\
(\mathrm{~kg} / \mathrm{c}\end{array}$ & mi $^{18}$ & 4.71 & 5.23 & 5.75 \\
\hline $40^{\circ}$ & 4.38 & 1 & 2 & 3 & 4 & 5 & 6 & 7 & 8 \\
\hline$\eta$ & 12.99 & 9 & 10 & 11 & 12 & 13 & 14 & 15 & 16 \\
\hline it & 24.31 & 17 & 18 & 19 & 20 & 21 & 22 & 23 & 24 \\
\hline $60^{\circ}$ & 4.38 & 25 & 26 & 27 & 28 & 29 & 30 & 31 & 32 \\
\hline$\prime \prime$ & 12.99 & 33 & 34 & 35 & 36 & 37 & 38 & 39 & 40 \\
\hline n & 24.31 & 41 & 42 & 43 & 44 & 45 & 46 & 47 & 48 \\
\hline $75^{\circ}$ & 4.38 & 49 & 50 & 51 & 52 & 53 & 54 & 55 & 56 \\
\hline " & 12.99 & 57 & 58 & 59 & 60 & 61 & 62 & 63 & 64 \\
\hline "t & 24.31 & 65 & 66 & 67 & 68 & 69 & 70 & 71 & 72 \\
\hline $88^{\circ}$ & 4.38 & 73 & 74 & 75 & 76 & 77 & 78 & 79 & 80 \\
\hline n & 12,99 & 81 & 82 & 83 & 84 & 85 & 86 & 87 & 88 \\
\hline$n$ & 24.31 & 89 & 90 & 91 & 92 & 93 & 94 & 95 & 96 \\
\hline
\end{tabular}

Table 6. Three-factor experimental arrangements. The figures $1 \sim 36$ correspond to the rotated factor loadings of fig. 5 .

\begin{tabular}{c|r|rrr}
\hline \multirow{2}{*}{ hardness } & $\begin{array}{r}\text { speed } \\
(\mathrm{m} / \mathrm{min})\end{array}$ & \multicolumn{3}{|c}{ load per linear cm } \\
\cline { 3 - 5 } & 2.09 & 3.66 & $5.75(\mathrm{~kg} / \mathrm{cm})$ \\
\hline $40^{\circ}$ & 4.38 & 1 & 2 & 3 \\
$\prime \prime$ & 12.99 & 4 & 5 & 6 \\
$60^{\circ}$ & 24.31 & 7 & 8 & 9 \\
$" \prime$ & 4.38 & 10 & 11 & 12 \\
$\prime \prime$ & 12.99 & 13 & 14 & 15 \\
$75^{\circ}$ & 24.31 & 16 & 17 & 18 \\
$\prime \prime$ & 4.38 & 19 & 20 & 21 \\
$" \prime$ & 12.99 & 22 & 23 & 24 \\
$88^{\circ}$ & 24.31 & 25 & 26 & 27 \\
$" \prime$ & 12.38 & 28 & 29 & 30 \\
$\prime \prime$ & 24.31 & 31 & 32 & 33 \\
\hline
\end{tabular}

析の結果とほば同じ炕なる

生体の分散の $75 \%$ 程度までを説明できるのる共通 因子mとすると Table 4.1 と Table 4.2 加

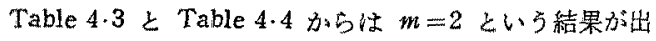

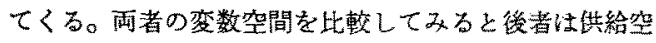
気圷を固定してしまったよらになっているので共通因子 数が減少したものと思われる。共通因子数の決定に際し て固有值の数が明礁にテスト变数より少なく出てきた

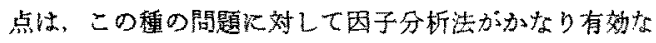

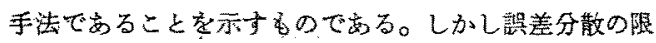

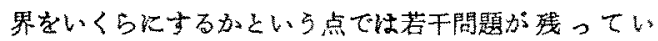
る。本実験の赛合には渱差分散の推定值として $1-\rho_{i}^{2}$

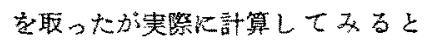
$\rho_{i}^{2}=1$ となってし来5のて，誤差分

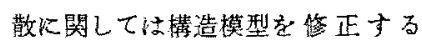

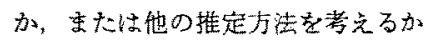
むる必萝がある。

共通因子を 3 として 96 变数の㺕 合之 36 禁数の場合とについて因子

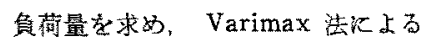
回䎐結果を Fig. 4 および Fig. 5 k 示す。Table 5 ならび Table 6 K

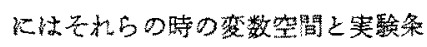
州之の效底を示す。艺こで共通因子 の物理的な意味が閐题になってくる がたとえば単位長当りの荷重が 最高の点を Fig. 4 からび Fig.5 にマークしてみると(四中のム印) いずれの場合も全体に散らばってし 


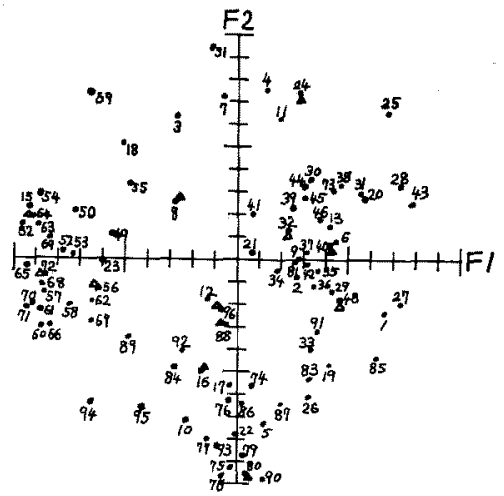

(a)

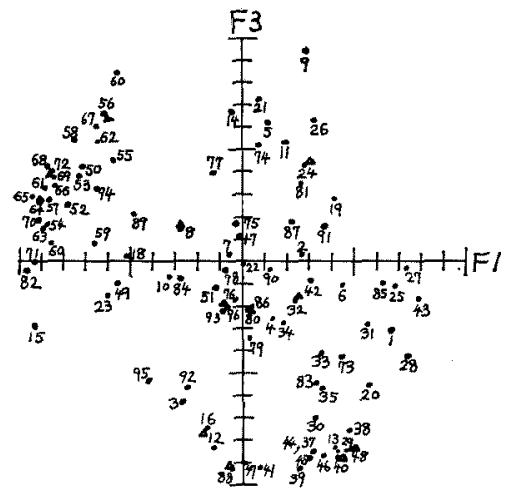

(b)

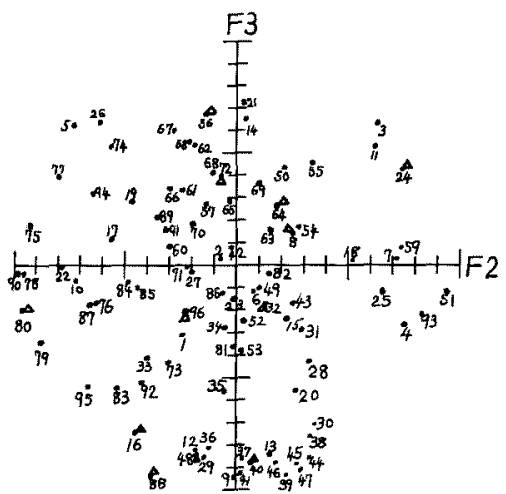

(C)

Fig. 4. Rotated factor loadings of $96 \times 96$ correlation matrix.
(a) : factors 1 and 2
(b) : factors 1 and 3
(c) : factors 2 and 3
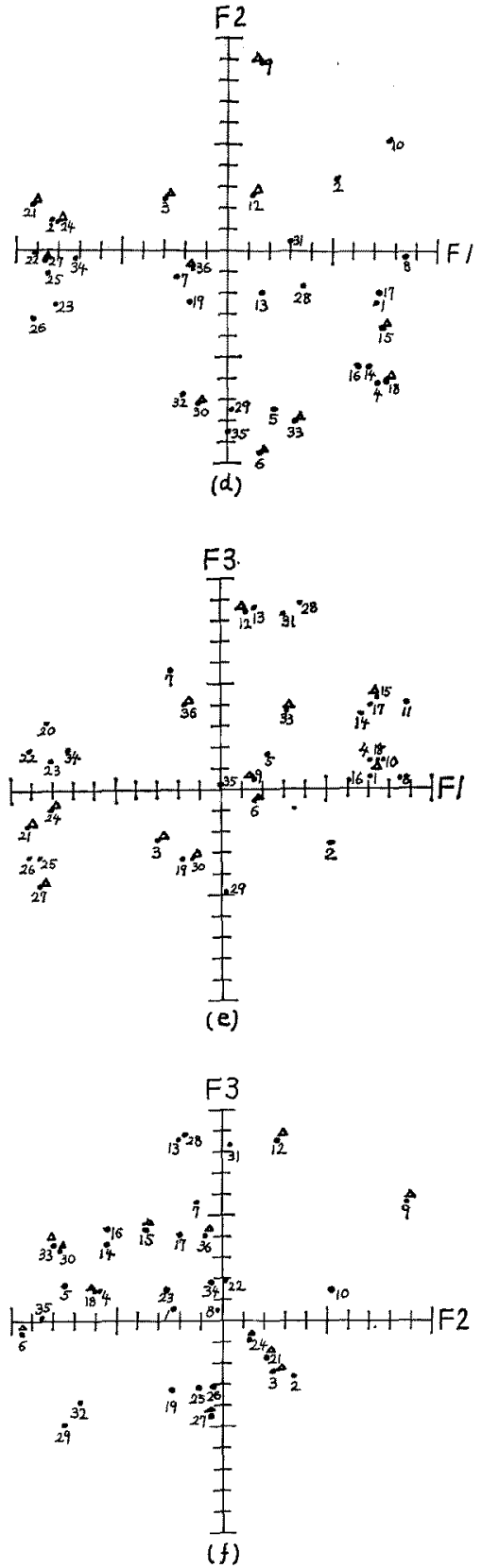

Fig. 5. Loadings on rotated factors obtained from analysis of correlation coefficients between the percentage of water retention of 36 variables.
(d) : factors 1 and 2
(e) : factors 1 and 3
(f) : factors 2 and 3 
まって，共通因子を解秎するには単位長さ当りの荷重と いう要因では不充分であることがわかる。同様汇速度の 要因をプロットしてみてもやはり解釈のためには不充分 であることがわかる。これらのことは分散分析の結果単 位長さ当りの荷重，速度，硬度の要因間化交互作用吕存 在したことを考完合せてる当然のことである。したがっ て共通因子を物理的澺味つけるためには因子負荷量を 別の要因によってプロットして判定すべきことがわか ๖。

\section{7. 結論}

從来経呀的に推測されていた動的な口ール絞り作用の 要因数を多变量解析特に主因分子析の手法を適用するこ とによって明確に定めることができ, その数学モデルを゙ 設定できることがかかった。すなかる布の状態を一定に 保占ロール硬度，荷重，通過速度を变化させて校り付着 量を貺定した場合に，硬度 $75^{\circ}$ では単位長さ当りの荷重 約 $3.0 \mathrm{~kg} / \mathrm{cm}$ か.5 $5.8 \mathrm{~kg} / \mathrm{cm}$ まで，硬度 $88^{\circ}$ では単 位長さ当り荷重 $2.0 \mathrm{~kg} / \mathrm{cm}$ から $5.8 \mathrm{~kg} / \mathrm{cm}$ をでの範
因内で怯，䜌り付着量が速度によって变化することがわ かった。さらに主因子分析によれば，布就よび溶液の条 件を一定にした場合には，付着量に影響を和よぼす要因 数性 3 個を取れ柱全分散の $75 \%$ を説明できることがわ かった。な和因子負荷量による要因の解积については筑 り付着量に影響を就よ゙゙すロール間の圧力分布の状態，

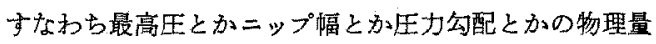
の変化と負荷因子量とを比較対応してみる必要がある。

終わりに本研究を進めるにあたりご指導いただきるし た東京工業大学石川章一数授深く感謝します。

文 献

1) H. Rath ; Textil Plaxis, 1, 65 (1954) E. Selter; Textil Plaxis, 2, 178 (1954)

2）田口玄一; 実䍄計画法 下, 犯着, p. 778

3) A.Ralston, H.S. Wilf; Mathematical Methods for Digital Computers, John Wiley \& Sons (1964) p. 224

4）北川, 国沢，柗口 編；因子分析，JUSE (1965) p. 9 